\title{
Alstroemeriaceae na Região Sul do Brasil
}

\author{
Alstroemeriaceae in South of Brazil
}

Marta Camargo de Assis ${ }^{1}$

\begin{abstract}
Resumo
Alstroemeriaceae compreende ervas perenes eretas ou volúveis, rizomatosas de folhas geralmente ressupinadas. É encontrada em quase todos os tipos de hábitats, de florestas a brejos e até desertos. A família está representada na Região Sul do Brasil pelo gênero Alstroemeria L., incluindo 9 espécies: Alstroemeria albescens M.C.Assis, A. amabilis M.C.Assis, A apertiflora Baker, A. cunha Vell., A. inodora Herb., A. isabelleana Herb., A. malmeana Kraenzl., A. psittacina Lehm., A. sellowiana Seub. ex Schenk, e pelo gênero Bomarea Mirb. incluindo apenas a espécie B. edulis (Tussac) Herb. Neste trabalho são apresentadas nova sinonimização, chaves de identificação, descrição das espécies, ilustrações e comentários.

Palavras-chave: Alstroemeria, Bomarea, flora, sistemática, Brasil
\end{abstract}

\begin{abstract}
Alstroemeriaceae comprises perennial herbs that are erect or twining and rhizomatous. The leaves are generally resupinate. They are found in a wide range of habitats including cloud forests, swamps and desert areas. The family is represented at South of Brazil by 2 genus: Alstroemeria L. and Bomarea Mirb. Alstroemeria included 9 species: Alstroemeria albescens M.C.Assis, A. amabilis M.C.Assis, A. apertiflora Baker, A. cunha Vell., A. inodora Herb., A. isabelleana Herb., A. malmeana Kraenzl., A. psittacina Lehm., A. sellowiana Seub. ex Schenk. Bomarea included just one specie, B. edulis (Tussac) Herb. New synonym, key to genera and species, descriptions, illustrations and comments are presented.
\end{abstract}

Key words: Alstroemeria, Bomarea, flora, systematic, Brazil

\section{Introdução}

Com um total de 201 espécies, Alstroemeriaceae abrange quatro gêneros: Alstroemeria L. com 75 espécies restritas à América do Sul, Bomarea Mirb. com 120 espécies distribuídas desde a região central do México até o sul da América do Sul, Luzuriaga Ruiz. et Pav. com quatro espécies de distribuição disjunta na Nova Zelândia e Chile e Drymophila R. Br. com uma espécie na Austrália e uma na Tasmânia (Assis 2001, 2004b, 2007; Conrad \& Clifford 1998). Os gêneros Luzuriaga e Drymophila pertenciam à família Luzuriagaceae considerada até então como grupo irmão de Alstroemeriaceae, mas por compartilharem o caráter de folhas ressupinadas, a família Luzuriagaceae foi incluída em Alstroemeriaceae de acordo com o sistema de classificação baseado em APG III (2009).

No Brasil estão representados os gêneros Alstroemeria e Bomarea. Alstroemeria com 44 espécies possui distribuição peri-amazônica concentrada basicamente na porção leste do país. Ocorre em quase todos os tipos de hábitats: florestas, cerrados, campos de altitude, brejos, afloramentos rochosos e caatingas, em altitudes que variam de 300 m, na Amazônia, a 2300 m, na Serra do Itatiaia, sendo que a maioria das espécies tem distribuição relativamente restrita (Assis 2001, 2002, 2003, 2004a, 2006, 2007, 2009; Assis \& Mello-Silva 2002; Sanso et al. 2005). Esta distribuição restrita contribui para que muitas das espécies sejam consideradas ameaçadas de extinção segundo os critérios da IUCN (2003), incluidas na categoria venerável (VU) e em perigo (EN). Para a Região Sul, as espécies $A$. amabilis M.C.Assis e $A$. apertiflora Baker estão incluídas na categoria VU e A. malmeana Kraenzl. em EN.

O gênero Bomarea está representado no Brasil apenas pela espécie Bomarea edulis (Tussac.) Herb., de ampla distribuição, ocorrendo

\footnotetext{
${ }^{1}$ Embrapa Meio Ambiente, Rod. SP-340 km 127,5, 13820-000, Jaguariúna, SP, Brasil. marta.assis@embrapa.br
} 
de norte a sul em borda e interior de Florestas Estacionais (Sanso \& Xifreda 2001; Assis 2004b, 2007).

O presente trabalho tem como objetivo o reconhecimento e delimitação das espécies de Alstroemeriaceae na Região Sul do Brasil, fornecendo chave de identificação, descrições, comentários e ilustrações das espécies, que auxiliem na correta identificação das mesmas.

\section{Material de Métodos}

Este estudo abrangeu os estados do Paraná, Santa Catarina e Rio Grande do Sul e foi baseado em observações de campo e na análise de materiais botânicos provenientes de herbários nacionais e estrangeiros ( B, BHCB, BR, C, CTES, ESA, F, G, HB, HUCS, IAC, ICN, INPA, K, MBM, MO, NY, PACA, PEL, R, RB, SP, SPF, UB, UEC, UPCB, W), citados conforme Holmgren et al. (1990).

A Região Sul compreende os estados do Paraná, Santa Catarina e Rio Grande do Sul, que juntos totalizam uma área de $576.300,8 \mathrm{~km}^{2}$. O clima dominante é o subtropical com temperaturas médias que variam de $14^{\circ} \mathrm{C}$ a $21^{\circ} \mathrm{C}$ onde as geadas são freqüentes e nos locais de altitudes mais elevadas também ocorrem eventualmente precipitações de neve (Boldrini 2002). Grande parte da região está sob o domínio da Mata atlântica que apresenta variações fito fisionômicas como Floresta Ombrófila Mista, Floresta Ombrófila, Floresta Estacional, Mata Nebular e Campos de Altitude enquanto que o Rio Grande do Sul abriga também o bioma Pampa. Este último é formado por quatro fito fisionomias campestres naturais:
Planalto da Campanha, Depressão Central, Planalto sul-Rio-Grandense e Planície Costeira, e mais ao sul do Rio Grande do Sul os campos sulinos (Silva 2002; MMA 2007).

\section{Resultados e discussão}

\section{Alstroemeriaceae}

Ervas eretas ou volúveis, 0,3-4 m alt.; rizoma simpodial, raízes delgadas ou espessadas. Folhas geralmente ressupinadas, alternas, membranáceas, cartáceas ou coriáceas, ambas as faces glabras ou face adaxial papilosa, lineares, lanceoladas, elípticas, obovais, oblongas a esptatuladas. Inflorescências terminais, raro axilares, em cimeiras umbeliformes simples ou compostas, raro flores solitárias. Brácteas foliosas, reduzidas ou ausentes. Flores epíginas, bissexuais, actinomorfas ou zigomorfas; de cor creme, esverdeadas, amareladas, alaranjadas, avermelhadas ou lilases. Tépalas petalóides, livres, as externas geralmente sem padrão de máculas ou menos manchadas que as internas. Tépalas internas punctadas, maculadas, listradas ou variegadas, a inferior geralmente mais estreita; margem proximal fortemente involuta formando um tubo revestido por tricomas glandulares secretores de néctar. Estames 6, exclusos ou inclusos. Filetes livres, cilíndricos, complanados na base e subulados no ápice. Anteras pseudobasifixas, deiscência introrsa e longitudinal. Estilete excluso ou incluso, trígono; estigma trífido, ramos papilosos. Ovário trilocular ou raramente unilocular; óvulos anátropos de placentação axilar ou parietal. Fruto cápsula loculicida, raro indeiscente. Sementes globosas com ou sem sarcotesta.

\section{Chave para identificação dos gêneros de Alstroemeriaceae no Brasil}

1. Ervas volúveis, flores actinomorfas, semente com sarcotesta

Bomarea edulis

1'. Ervas eretas, flores zigomorfas, raro actinomorfas, semente sem sarcotesta Alstroemeria

\section{Alstroemeria L.}

Ervas eretas; ramos vegetativos e reprodutivos diferentes entre si. Folhas glabras ou papilosas na face adaxial, lâminas linear-lanceoladas, oblongas, elípticas ou espatuladas, geralmente ressupinadas. Inflorescência em cimeira umbeliforme simples ou composta. Flores bissexuais, epígenas, zigomorfas, pendentes ou patentes, campanuladas ou tubulosas, protrândricas; tépalas livres, eretas ou reflexas; as externas e internas com padrões de máculas rubro-maculadas, rubro-punctadas, rubro-listradas ou rubro-variegadas; nectários perigonais na base de 2-3 tépalas internas; estames 6, filetes cilíndricos, glabros ou papilosos na base, anteras alongadas pseudo-basifixas, de deiscência longitudinal introrsa; ovário trilocular, numerosos óvulos anátropos de placentação axilar ou parietal; estilete simples, estigma trífido. Cápsula loculicida; sementes sem sarcotesta, globosas cinéreo-acastanhadas. 


\section{Chave para identificação das espécies de Alstroemeria no Sul do Brasil}

1. Folhas cartáceas ou coriáceas.

2. Estames exclusos.

3. Flores lilases ou alvo-lilases, patentes, campanuladas; tépalas externas sem máculas e internas rubro-punctadas 1. A. albescens

3'. Flores alaranjadas ou avermelhadas.

4. Folhas do ramo reprodutivo semi-amplexicaules; flores patentes,campanuladas, vermelhas ou alaranjadas; tépalas reflexas, as externas sem máculas e as internas rubro-punctadas 3. A. apertiflora

4'. Folhas do ramo reprodutivo amplexicaules; flores pêndulas, campanuladas a urceoladas, vermelhas; tépalas não reflexas, externas e internas sem máculas 7. A. malmeana

2'. Estames inclusos.

5. Folhas do ramo vegetativo linear-lanceoladas, concentradas no terço distal do ramo; flores amareladas a alaranjadas; tépalas internas rubro-punctadas 9. A. sellowiana

5'. Folhas do ramo vegetativo, oblongas a elípticas ou elíptico-lanceoladas, distribuídas por todo o ramo; flores vermelhas, alaranjadas, rosadas ou creme-esverdeadas; tépalas internas rubro-maculadas e/ou rubro-listradas.

6. Folhas do ramo reprodutivo elípticas, elíptico-lanceoladas ou oblongo-lanceoladas, papilosas na face adaxial, distribuídas por todo o ramo; flores patentes, campanuladas, vermelhas ou alaranjadas; tépalas internas rubro-maculadas e listradas .... 2. A. amabilis

6'. Folhas do ramo reprodutivo elíptico-lanceoladas, glabras em ambas as faces, raramente papilosa na face adaxial, distribuídas no terço distal do ramo; flores pêndulas, tubulosas, rosadas, alaranjadas, vermelhas ou creme-esverdeadas, ápice verde; tépalas internas rubro-listradas

6. A. isabelleana

1'. Folhas membranáceas.

7. Flores vermelho-alaranjadas; tépalas externas sem máculas, tépalas internas rubro-listradas e maculadas; filetes papilosos no terço proximal 4. A. cunha

7'. Flores vermelhas ou vermelho-esverdeadas; tépalas externas e internas com máculas; filetes glabros. 8. Flores vermelho-esverdeadas, tépalas externas e internas rubro-maculadas, ápice esverdeado .. 8. A. psittacina

8'. Flores vermelhas, tépalas externas rubro-variegadas e tépalas internas rubro-listradas 5. A. inodora

1. Alstroemeria albescens M.C.Assis, Novon 19 (2): 145-149. 2009.

Fig. 1a-c

Erva ereta $0,7 \mathrm{~m}$; ramos cilíndricos, glabros. Folhas não ressupinadas, coriáceas, distribuídas por todo o ramo, lineares a linear-lanceoladas, as do ramo vegetativo $1,5-11,5 \times 0,4-0,5 \mathrm{~cm}$, ápice acuminado, base cuneada, ambas as faces glabras, as do ramo reprodutivo $1,5-6,0 \times 0,4-0,6 \mathrm{~cm}$, ápice acuminado, base truncada, ambas as faces glabras. Cimeira umbeliforme composta, pedicelo glabro, 2-2,5 cm ; brácteas foliosas, cartáceas, $0,8-0,9$ cm compr.; bractéolas membranáceas, $0,3-0,5 \mathrm{~cm}$ compr. Flores patentes, campanuladas, lilases ou alvo-lilases, 2,2-3 cm compr. Tépalas externas sem máculas, similares entre si, ápice agudo a mucronado, base atenuada a superior $2 \times 0,8 \mathrm{~cm}$ as inferiores $1,9 \times 0,7 \mathrm{~cm}$; tépalas internas rubropunctadas, similares entre si; a superior $1,9 \times 0,5 \mathrm{~cm}$; as inferiores $1,9 \times 0,5 \mathrm{~cm}$. Estames exclusos, filetes glabros 1-2 cm. Estigma incluso, estilete glabro, $1,5-1,6 \mathrm{~cm}$. Cápsula não vista.

Material examinado: RIO GRANDE DO SUL: Porto Alegre, Morro São Pedro, 26.I.2006, fl., R.B. Setúbal 659 (ICN); 21.I.2007, fl., R.B. Setúbal 204 (ICN, HB, K, MO); fl., R.B. Setúbal 246 (ICN); fl., R.B. Setúbal 200 (UEC); 3.III.2007, fr., R.B. Setúbal \& D. Fuhro 201 (ICN).

Alstroemeria albescens ocorre em afloramento rochoso e é endêmica do Morro São Pedro em Porto Alegre, Rio Grande do Sul. Floresce de janeiro a março e frutifica em março.

É caracterizada por suas flores lilases ou alvolilases e tépalas internas rubro-punctadas. Os ramos vegetativos de folhas estreitas distribuídas por todo o ramo são muito similares às de $A$. amabilis, A. apertiflora, A. isabelleana Herb., A. malmeana A A sellowiana Seub. ex Schenk, que também ocorrem no Rio Grande do Sul, mas são diferenciadas de $A$. albescens principalmente pelos caracteres florais (Tab. 1). 

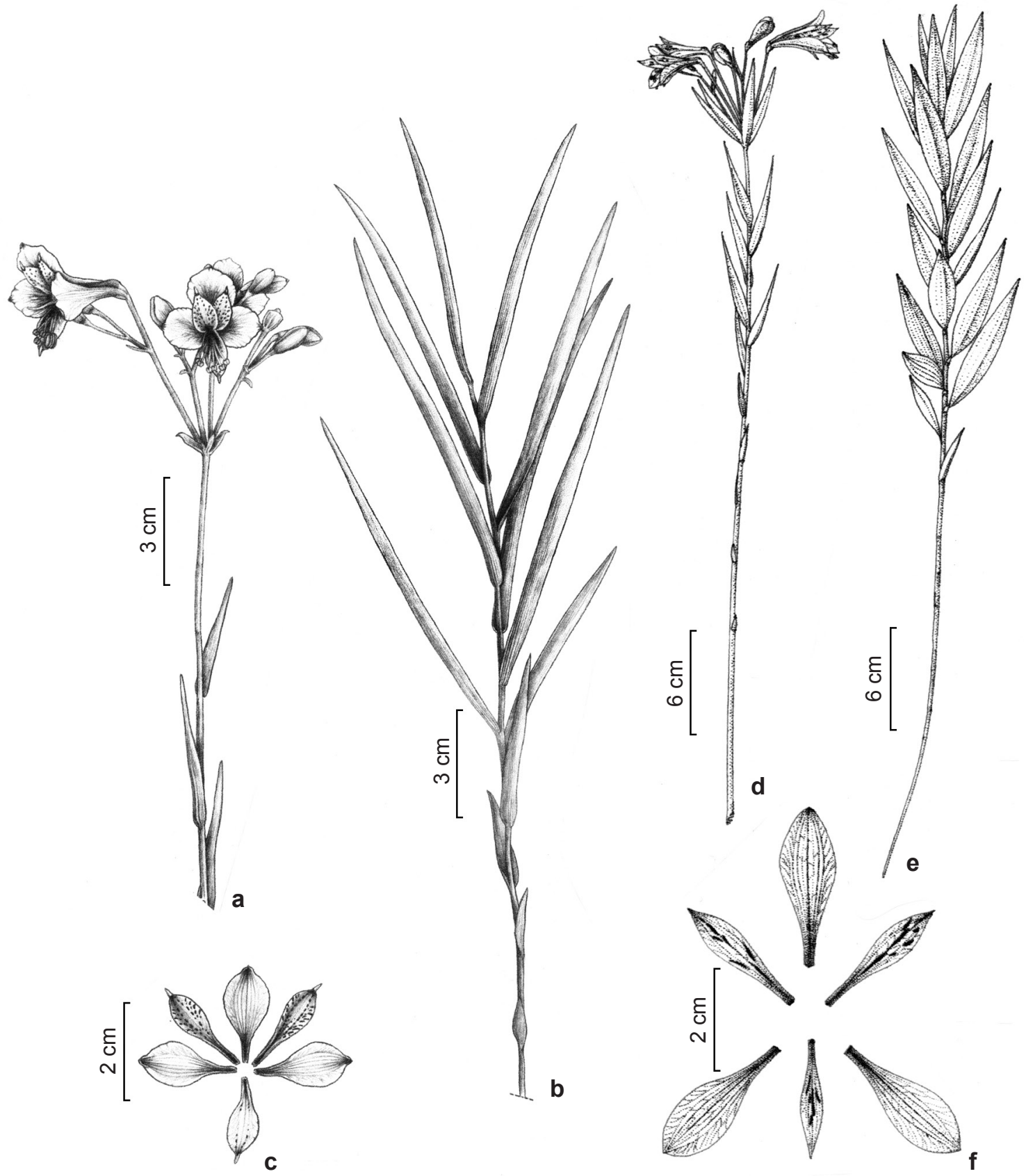

Figura 1 - a-c. A. albescens - a. parte do ramo reprodutivo mostrando inflorescência umbeliforme composta e brácteas reduzidas; b. ramo vegetativo; c. flores mostrando tépalas internas rubro-punctadas (Setúbal 204). d-f. A. amabilis - d. parte do ramo reprodutivo mostrando inflorescência umbeliforme simples e brácteas desenvolvidas; e. ramo vegetativo; f. flor mostrando tépalas internas rubro-listradas e maculadas (Kummrow 3387).

Figure 1 - a-c. A. albescens - a. part of reproductive branch showing compound umbel and reduced bracts; b. vegetative branch; c. flowers showing red-punctate inner tepals (Setúbal 204). d-f. A. amabilis - d. part of branch reproductive showing umbel simple and develop bracts; e. vegetative branch; f. flower showing inner tepals red-striped and stained (Kummrow 3387). 
2. Alstroemeria amabilis M.C.Assis, Acta bot. bras. 17(2): 182-182. 2003.

Fig. 1d-f

Erva ereta $0,6-1,1 \mathrm{~m}$ alt.; ramos angulosos, ligeiramente papilosos no terço proximal. Folhas não ressupinadas, cartáceas ou coriáceas, distribuídas por todo o ramo, as do ramo vegetativo 7-9 $\times 1-2$ $\mathrm{cm}$, oblongas a elípticas, ápice acuminado, base canaliculada, face adaxial glabrescente, abaxial glabra, nervação proeminente em ambas as faces, as do ramo reprodutivo, adpressas ou semiamplexicaules, 1,5-6,5 ×0,4-0,9 cm, elípticas a elíptico-lanceoladas ou oblongo-lanceoladas, ápice agudo a acuminado, base cuneada; face adaxial papilosa, abaxial glabra, nervação proeminente em ambas as faces. Cimeira umbeliforme simples, raro composta; pedicelo glabro, 2,2-3,5 cm compr.; brácteas foliosas, cartáceas, 1,5-2,5 ×0,3-0,7 cm; bractéolas cartáceas, $0,6-1,7 \times 0,2-0,4 \mathrm{~cm}$, elípticas a linear-lanceoladas. Flores patentes, sem odor, campanuladas, vermelhas ou alaranjadas, 2,5-3,5 cm compr. Tépalas externas sem máculas, similares entre si, obovadas a espatuladas, ápice agudo a mucronado, base atenuada; a superior $3 \times 1 \mathrm{~cm}$; as inferiores 3,3 $\times 1,1 \mathrm{~cm}$; tépalas internas rubromaculadas e listradas, similares entre si, espatuladas, ápice acuminado, base atenuada, margem distal inteira ou ligeiramente crenulada; as superiores ca. $3 \times 0,6 \mathrm{~cm}$; a inferior ca. $2,2 \times 0,5 \mathrm{~cm}$. Estames inclusos, filetes glabros, ca. $3 \mathrm{~cm}$ compr. Estigma incluso, estilete glabro, ca. $2,5 \mathrm{~cm}$ compr. Cápsula globosa, 1-1,6 × 1,2-1,6 cm.

Material examinado: PARANÁ: Campina Grande do Sul, Pico Caratuva, 20.V.1967, fr., G. Hatschbach 16455 (MBM, UPCB); 8.II.1968, fl., G. Hatschbach 18566 (MBM); Serra do Capivari Grande, 2.II.1990, fl., O.S. Ribas \& V. Nicolack 239 (MBM); 13.III.1990, fl. e fr., J. Cordeiro \& J.M. Silva 721 (MBM); 15.I.1969, fl., G. Hatschbach \& C. Koczicki 20747 (MBM); Serra Ibitiraquire, 23.I.1970, fl., G. Hatschbach 23399 (MBM). Guaratuba: Serra de Araçatuba, 31.XI.1960, fl., G. Hatschbach 6698 (MBM); 10.III.1959, fl. e fr., $G$. Hatschbach 5553 (MBM); 13.IV.1983, fl., R. Kummrow 2282 (MBM). Morretes: Pico Olimpo, Serra Marumbi, 23.II.1947, fl. e fr., O. Curial 682 (F, MBM, PACA, SP); Pico Olimpo, 26.II.1950, fl., G. Hatschbach 1877 (MBM); Serra Marumbi, 27.II.1970, fl., G. Hatschbach 23937 (MBM); elev. 1500 m, 27.III.1994, fl., A.A.F.C. Tombolato 540 (IAC). Quatro Barras: Morro Mãe Catira, 9.IV.1986, fl. e fr., J. Cordeiro \& F. J. Zelma 281 (MBM); SANTA CATARINA. Campo Alegre: Serra do Quiriri, 14.I.1998, fl., O. S. Ribas et al. 2252 (MBM).

Alstroemeria amabilis é encontrada em locais úmidos e elevados do Paraná e Santa Catarina, florescendo de dezembro a março e frutificando de março a maio.
É caracterizada pelas flores com tépalas externas sem máculas, obovado-espatuladas de ápice agudo e as tépalas internas rubro-listradas, espatuladas de ápice acuminado. Alstroemeria amabilis é semelhante a A. sellowiana, mas esta tem flores odoríferas e as tépalas internas e externas semelhantes entre si, espatuladas de ápice mucronado, sendo as internas rubro-punctadas, enquanto que em $A$. amabilis as tépalas internas e externas são bem diferentes entre si. Os ramos vegetativos de $A$. amabilis são semelhantes aos de $A$. albescens, $A$. apertiflora, A. isabelleana, A. malmeana e A. sellowiana, mas são diferenciados de A. amabilis pelas folhas glabras, enquanto que em A. amabilis as folhas são papilosas na face adaxial.

\section{Alstroemeria apertiflora Baker, Handb.} Amaryll. 135. 1888.

Fig. 2a-d

Erva ereta $0,5-1,5 \mathrm{~m}$ alt.; ramos angulosos, glabros. Folhas não ressupinadas, cartáceas ou coriáceas, as do do ramo vegetativo distribuídas por todo ramo, $2,2-8 \times 0,2-0,6 \mathrm{~cm}$, lanceoladas, ápice longamente acuminado, base cuneada, ambas as faces glabras com nervuras proeminentes, as do ramo reprodutivo semi-amplexicaules ou não amplexicaules, distribuídas na metade distal do ramo, 2,2-8 × 0,2-0,6 cm, lanceoladas, ápice longamente acuminado, base cuneada, ambas as faces glabras com nervuras proeminentes. Cimeira umbeliforme composta, pedicelo glabro, 10-20 cm compr.; brácteas foliosas reduzidas, cartáceas, $0,2-0,5 \times 0,2-0,3 \mathrm{~cm}$; bractéolas semelhantes às brácteas, membranáceas, $0,4-0,7 \times 0,2-0,3 \mathrm{~cm}$. Flores patentes, sem odor, campanuladas, vermelhas ou alaranjadas, 1,9-3,0 cm compr. Tépalas externas sem máculas, reflexas, iguais entre si, 1,9-2,1 $\times 0,5 \mathrm{~cm}$, elíptico-espatuladas, ápice agudo ou acuminado, base atenuada; tépalas internas internamente rubro-puncatadas, reflexas, iguais entre si, 1,8-2,3 × 0,2 cm, lanceoladas, ápice agudo ou acuminado, base atenuada, margem distal inteira. Estames exclusos, filetes glabros, ca. 2,3 cm compr. Estigma excluso, estilete glabro, 1,7-2 cm compr. Cápsula ovóide, $1-1,2 \times 0,8-0,9 \mathrm{~cm}$.

Material examinado: PARANÁ: Colombo, Rio Palmital, 1.XI.1973, fl., G. Hatschbach 32798 (MBM). Contenda,Rodovia do Xisto, 22.X.1967, fl., G. Hatschbach 17552 (B, F, MBM). Curitiba: 13.IX.1915, fl., P. Dusén 17183 (F); Atuba, 16.XI.1960, fl., G. Hatschbach 7471 (MBM); entre Curitiba e Pinhais, 13.XI.1909, fl., P. Dusén 8910 (G, K). Cachimba, 28.XI.1984, fl., R. Kummrow 2548 (MBM). Boqueirão, 8.X.1987, fl., J.M. Silva 335 (G, MBM, PACA, UPCB). 


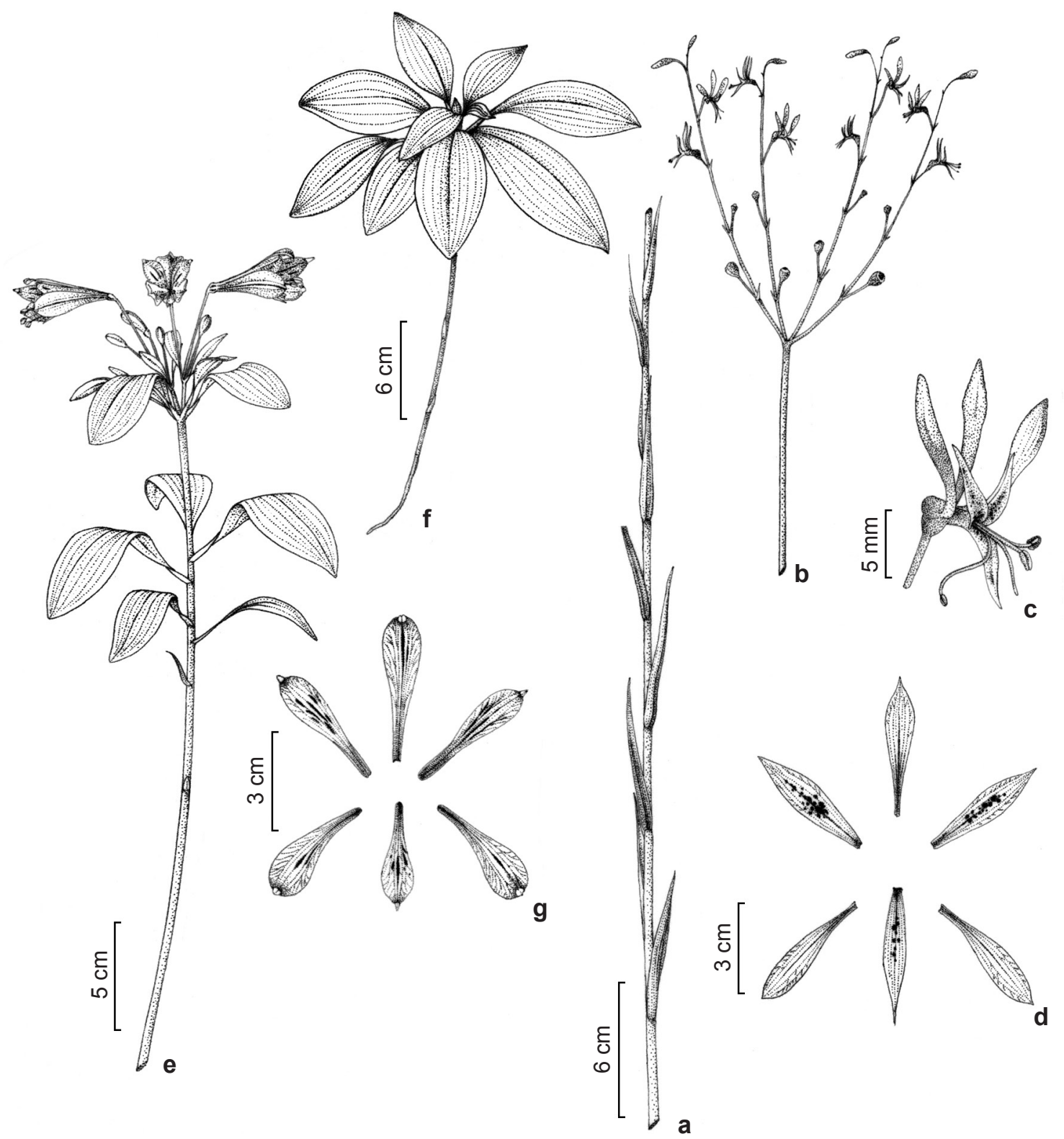

Figura 2 - a-d. A. apertiflora - a. parte do ramo vegetativo; b. parte do ramo reprodutivo mostrando inflorescêcnia composta e brácteas reduzidas; c. flor mostrando tépalas externas reflexas; d. flor mostrando tépalas internas rubro-punctadas (Souza 4691). e-g. A. cunha-e. ramo vegetativo; f. parte do ramo reprodutivo mostrando inflorescência umbeliforme simples e brácteas bem desenvolvidas; g. flor mostrando tépalas internas rubro-maculadas (Hunt 6489).

Figure 2 - a-d. A. apertiflora - a. part of vegetative branch; b. part of reproductive branch showing umbel compound and reduced bracts; c. flower showing outer tepals reflex; d. flower showing inner tepals red-punctate (Souza 4691). e-g. A. cunha - e. vegetative branch; f. part of reproductive branch showing umbel simple and develop bracts; g. flower showing inner tepals red-stained (Hunt 6489).

Recanto das Araucárias, 22.XI.1989, fl., C. Budziak \& J. Cordeiro 38 (MBM). Palmeiras, Rio dos Papagaios, 5.XII.1987, fl., Shirata 700 (MBM); Recanto dos Papagaios, 28.X.1996, fl., O.S. Ribas \& M.F. Luz 1554 (MBM). Lapa, Engenheiro Bley, 26.IX.1948, fl., G. Hatschbach 1086(MBM). Palmas, Estrada Ponte Serrada em direção a Palmas, 5.XII.1971, fl., G. Hatschbach et al. 28252 (MBM). Piraquara, Borda do Campo, Passo do Cercado, 20.X.1946, fl., G. Hatschbach 503 (MBM, PACA); estrada Rio Taquari-Rio Divisa, 13.XI.1949, fl., G. Hatschbach 1624 (MBM). Pinhais, 1.III.1970, fl., G. Hatschbach 23978 (MBM); 3.XII.1970, fl., G. Hatschbach 25733 (MBM). São Roque, 9.XII.1986, fl., J.M. Silva \& J. Cordeiro 264 (ESA, MBM). São José dos 
Tabela1 - Caracteres morfológicos distintivos entre as espécies Alstroemeria albescens, A. amabilis, A. apertiflora, A. isabelleana, A. malmeana e A. sellowiana.

Table 1 - Morphological characters distinguishing species Alstroemeria albescens, A. amabilis, A. apertiflora, A. isabelleana, A. malmeana e A. sellowiana.

\begin{tabular}{|c|c|c|c|c|c|c|}
\hline Caracrteres & $\begin{array}{l}\text { Alstroemeria } \\
\text { albescens }\end{array}$ & $\begin{array}{l}\text { Alstroemeria } \\
\text { amabilis }\end{array}$ & $\begin{array}{l}\text { Alstroemeria } \\
\text { apertiflora }\end{array}$ & $\begin{array}{l}\text { Alstroemeria } \\
\text { isabelleana }\end{array}$ & $\begin{array}{l}\text { Alstroemeria } \\
\text { malmeana }\end{array}$ & $\begin{array}{l}\text { Alstroemeria } \\
\text { sellowiana }\end{array}$ \\
\hline Flor & Campanulada & Campanulada & Campanulada & Tubulosa & $\begin{array}{l}\text { Campanulada a } \\
\text { urceolada }\end{array}$ & Campanulada \\
\hline $\begin{array}{l}\text { Coloração da } \\
\text { flor }\end{array}$ & $\begin{array}{l}\text { Lilás ou alvo- } \\
\text { lilás }\end{array}$ & $\begin{array}{l}\text { Vermelha ou } \\
\text { alaranjada }\end{array}$ & $\begin{array}{l}\text { Vermelha ou } \\
\text { alaranjadas }\end{array}$ & $\begin{array}{l}\text { Rosadas, } \\
\text { alaranjadas, } \\
\text { vermelhas } \\
\text { ou creme- } \\
\text { esverdeadas }\end{array}$ & Vermelhas & $\begin{array}{l}\text { Amareladas a } \\
\text { alaranjadas }\end{array}$ \\
\hline $\begin{array}{l}\text { Tépalas } \\
\text { externas }\end{array}$ & Não reflexas & Não reflexas & Reflexas & Não reflexas & Não reflexas & Não reflexas \\
\hline $\begin{array}{l}\text { Tépalas } \\
\text { internas }\end{array}$ & $\begin{array}{l}\text { Rubro- } \\
\text { punctadas }\end{array}$ & $\begin{array}{l}\text { Rubro- } \\
\text { maculadas e } \\
\text { listradas }\end{array}$ & Rubro-punctadas & Rubro-listradas & Sem máculas & $\begin{array}{l}\text { Rubro- } \\
\text { punctadas }\end{array}$ \\
\hline Cimeira & Composta & $\begin{array}{l}\text { Simples, raro } \\
\text { composta }\end{array}$ & Composta & Simples & Composta & $\begin{array}{l}\text { Simples ou } \\
\text { composta }\end{array}$ \\
\hline $\begin{array}{l}\text { Folhas } \\
\text { do ramo } \\
\text { vegetativo }\end{array}$ & $\begin{array}{l}\text { Lineares } \\
\text { a linear- } \\
\text { lanceoladas, } \\
\text { glabras }\end{array}$ & $\begin{array}{l}\text { Oblongas } \\
\text { a elípticas, } \\
\text { face adaxial } \\
\text { papilosa }\end{array}$ & $\begin{array}{l}\text { Lanceoladas, } \\
\text { glabras }\end{array}$ & $\begin{array}{l}\text { Elíptico- } \\
\text { lanceoladas, } \\
\text { raro papilosa }\end{array}$ & $\begin{array}{l}\text { Lineares } \\
\text { ou linear- } \\
\text { lanceoladas, } \\
\text { glabras }\end{array}$ & Lanceoladas \\
\hline Estames & Exclusos & Inclusos & Exclusos & Inclusos & Exclusos & Inclusos \\
\hline
\end{tabular}

Pinhais, Rio Miringuava, 18.XII.1968, fl., G. Hatschbach 20627 (MBM); Rio Pequeno, elev. 900 m, 5.XI.1969, fl., G. Hatschbach \& P. Ravenna 22816(MBM); 20.X.1994, fl., O.S. Ribas \& J. Cordeiro 687 (BHCB, G, MBM, UB); 7.XI.1996, fl., O.S. Ribas et al. 1598 (MBM); Teixeira Soares: Rio das Almas, 10.XII.1966, fl., G. Hatschbach 15355 (UEC). Tijucas do Sul, Rincão, 14.XII.1972, fl., G. Hatschbach 30993 (MBM); 21.X.1977, fl., G. Hatschbach 40447 (INPA, UEC). Campina, 11.I.1983, fl., R. Kummrow 2153 (MBM). RIO GRANDE DO SUL: 29.I.1942, fl., B. Rambo s.n. (PACA 9773). SANTA CATARINA: Campo Alegre, Fazenda de Ernesto Scheide, elev. 900 m, 11.XII.1956, fl., L.B. Smith \& R. Klein 8560 (R).

Alstroemeria apertiflora é encontrada na Argentina, Paraguai e no Brasil, ocorrendo sempre em regiões brejosas, do Rio Grande do Sul a Goiás e Minas Gerais. Floresce principalmente de outubro a março e frutifica de janeiro a março.

Como o nome indica, possui suas tépalas internas e externas reflexas, o que a torna facilmente identificável. O ramo vegetativo de $A$. apertiflora é muito semelhante ao ramo vegetativo de $A$. albescens, A. amabilis, A. isabelleana, A. malmeana e $A$. sellowiana. Todas estas espécies ocorrem em locais úmidos e apresentam o ramo vegetativo coberto por folhas estreitas, sendo muito difícil diferenciá-las neste estágio. As diferenças aparecem na fase reprodutiva através dos caracteres florais (Tab. 1).

4. Alstroemeria cunha Vell., Fl. flumin. 3(1): 131. 1829 (1825); Icon. 3: 121. 1831 (1827).

Fig. 2e-g

Erva ereta 0,2-1,5 m alt.; ramos cilíndricos, glabros. Folhas do ramo vegetativo ressupinadas, membranáceas, concentradas no terço distal do ramo, 2,5-10(-13) × 1-3(-4,8) cm, elípticas ou obovadas, ápice agudo, base atenuada, glabras ou papilosas na face adaxial, face abaxial glabra, nervuras não proeminentes, as do ramo reprodutivo ressupinadas, não amplexicaules, membranáceas, distribuídas por todo o ramo, (1,7-)2,5-10,5(-14) $\times(0,3-) 0,5-2,2(-4) \mathrm{cm}$, elípticas ou oblongas, ápice agudo ou acuminado, base atenuada, glabras ou papilosas na face adaxial, face abaxial glabra, nervuras não proeminentes. Cimeira umbeliforme simples, pedicelo glabro, 2-5 $(10,5) \mathrm{cm}$ compr.; brácteas foliosas, membranáceas, 2,5-5,7(-8) × $1-2,5 \mathrm{~cm}$; bractéolas não vistas. Flores patentes, sem odor, campanuladas, vermelho-alaranjadas, (2,5-)3-4,5 cm compr. Tépalas externas sem máculas, similares entre si, obovadas, ápice 
retuso a rotundo, base atenuada; a superior 2,4-3 $\times$ $1-1,3 \mathrm{~cm}$; as inferiores 2,6-2,8 × 1-1,2 cm.; tépalas internas rubro-listradas e maculadas, similares entre si, lanceolado-espatuladas, ápice agudo ou acuminado, margem distal inteira ou ligeiramente crenulada; as superiores 2,4-2,8 $\times 0,3-0,7 \mathrm{~cm}$; a inferior 2,2-2,4 $\times$ $0,4 \mathrm{~cm}$. Estames exclusos ou inclusos, filetes papilosos no terço proximal, 2,2-3,5 cm compr.; estigma incluso, estilete glabro, 2,2-3 cm compr. Cápsula não vista. Material examinado: PARANÁ: X.1965, fl., D. Souza 1 (MBM). Adrianópolis, Boa Vista, 27.VII.1987, fl., G. Hatchbach \& J.M. Silva 51283 (MBM). Cerro Azul, Ribeirão do Tigre, 12.X.1993, fl., G. Hatschbach et al. 59215 (MBM). Sapopema, Salto das Orquídeas, 27.IX.1997, fl., C. Medri et al. 455 (SPF). Tunas do Paraná, Parque Estadual de Campinhos, 11.XI.1998, fl., J.M. Silva \& L.M. Abe 2624 (MBM).

Alstroemeria cunha é frequentemente encontrada no Espírito Santo, Minas Gerais, Rio de Janeiro, São Paulo e Paraná, no interior de florestas estacionais semidecíduas. Floresce esporadicamente o ano inteiro, mais intensamente de novembro a março.

Possui uma grande amplitude de variação nas dimensões do ramo, disposição e no indumento das folhas. Além disso, as flores podem apresentar estames exclusos ou inclusos e também variam bastante nas dimensões. Assim, o que caracteriza a espécie é o ramo reprodutivo com folhas membranáceas distribuídas por todo o ramo, juntamente com as flores de tépalas externas sem máculas, obovadas com ápice retuso a rotundo e tépalas internas rubro-listradas e maculadas, lanceolado-espatuladas, de ápice agudo ou acuminado.

O ramo vegetativo de $A$. cunha caracterizado pelas folhas mebranáceas concentradas no terço distal do ramo, se assemelha aos ramos de $A$. inodora e $A$. psittacina Lehm. sendo muito difícil distinguir as espécies neste estágio. No entanto, a distinção entre elas é possível no estágio reprodutivo pelos caracteres florais. A. cunha Vell. apresenta tépalas externas sem máculas enquanto que em $A$. inodora Herb. são rubro-variegadas e em $A$. psittacina são rubro-maculadas.

5. Alstroemeria inodora Herb., Amaryllidaceae 90, tab. 2 fig. 1-5. 1837.

Fig. 3a-c

Erva ereta $0,2-1 \mathrm{~m}$ alt.; ramos cilíndricos glabros. Folhas do ramo vegetativo ressupinadas, membranáceas, concentradas no terço distal do ramo, 7-14 × 0,6-4,5 cm, elípticas, ápice agudo a acuminado, base atenuada, face adaxial papilosa com nervuras proeminentes e abaxial glabra sem nervuras proeminentes, as do ramo reprodutivo ressupinadas, não amplexicaules, membranáceas, distribuídas por todo o ramo, 2,5-6,5 × 0,5-1,6 $\mathrm{cm}$, elípticas, ápice acuminado, base atenuada, face adaxial papilosa com nervuras proeminentes, abaxial glabra sem nervuras proeminentes. Cimeira umbeliforme, simples, pedicelos glabros, 2,6-5 cm compr.; brácteas foliosas, membranáceas, 2-3,5 × 0,5-1,1 cm; bractéolas membranáceas, $0,3-1,8 \times 0,1-0,2 \mathrm{~cm}$. Flores patentes, sem odor, campanuladas, vermelhas, 3,7-4 cm compr. Tépalas extenas rubro-variegadas no terço distal, similares entre si, espatuladas, ápice rotundo apiculado, base atenuada; a superior ca. 3,6 $\times$ $0,7 \mathrm{~cm}$; as inferiores ca. $3 \times 0,8 \mathrm{~cm}$; tépalas internas rubro-listradas, similares entre si, linearespatuladas, ápice acuminado, base atenuada, margem distal inteira ou ligeiramente crenulada; as superiores, 3,5 ×0,4 cm; a inferior ca. 2,7 ×0,4 $\mathrm{cm}$. Estames inclusos, filetes glabros, $1,5-3 \mathrm{~cm}$ compr.; estigma incluso, estilete glabro, 2-2,9 cm compr. Cápsula elipsóide a largamente ovóide, $1,2-1,7 \times 0,8-1,4 \mathrm{~cm}$.

Material examinado: PARANÁ: Jaguariaíva, Rodovia PR-11, próximo ao rio Cajuru, 18.XI.1989, fl., G. Hatschbach et al. 53618 (C, MBM). São José da Boa Vista, Rio Jaguariaíva, Corredeira Paulista, 19.XI.1970, fr., G. Hatschbach 25566(MBM). Sengês, 6.X.1971, fl., G. Hatschbach 27099 (C, CTES, MBM, SP). Ventania, Rio Laranjinha, 17.X.1997, fl., G. Hatschbach \& E. Barbosa 67148 (MBM); 4.IX.1998, fl., G. Hatschbach \& J. M. Silva 68303 (MBM). RIO GRANDE DO SUL: Alto da Serra, 27.VI.1947, fl., G. Hatschbach 755 (PACA). Cerro Largo, 17.X.1946, fl., I. Augusto (PACA 34365). Piedade, 23.XII.1940, fr., B. Rambo (PACA 3664). Porto Alegre, 3.I.1933, fl., B. Rambo (PACA 788); 5.XI.1933, fl., B. Rambo s.n. (PACA 33945). SANTA CATARINA: Itapiranga, Barra do Macaco Branco $27^{\circ} 10^{\prime} \mathrm{S} 53^{\circ} 46^{\prime} \mathrm{W}$ elev. 150-250 m, 18/X/1964, fl., L.B. Smith \& R. Heitz 12701 (B, F, R).

Alstroemeria inodora ocorre no interior das florestas estacionais semidecíduas de São Paulo ao Rio Grande do Sul. Floresce geralmente de outubro a janeiro e frutifica em dezembro e março.

É caracterizada por apresentar as folhas membranáceas juntamente com as flores de tépalas externas rubro-variegadas e internas rubrolistradas. Esta espécie é semelhante a $A$. psittacina e $A$. cunha que se diferenciam pelas tépalas. Enquanto $A$. psittacina possui as tépalas externas e internas rubro-maculadas, em $A$. cunha as tépalas externas não possuem máculas e as internas são rubro-maculadas e listradas. 


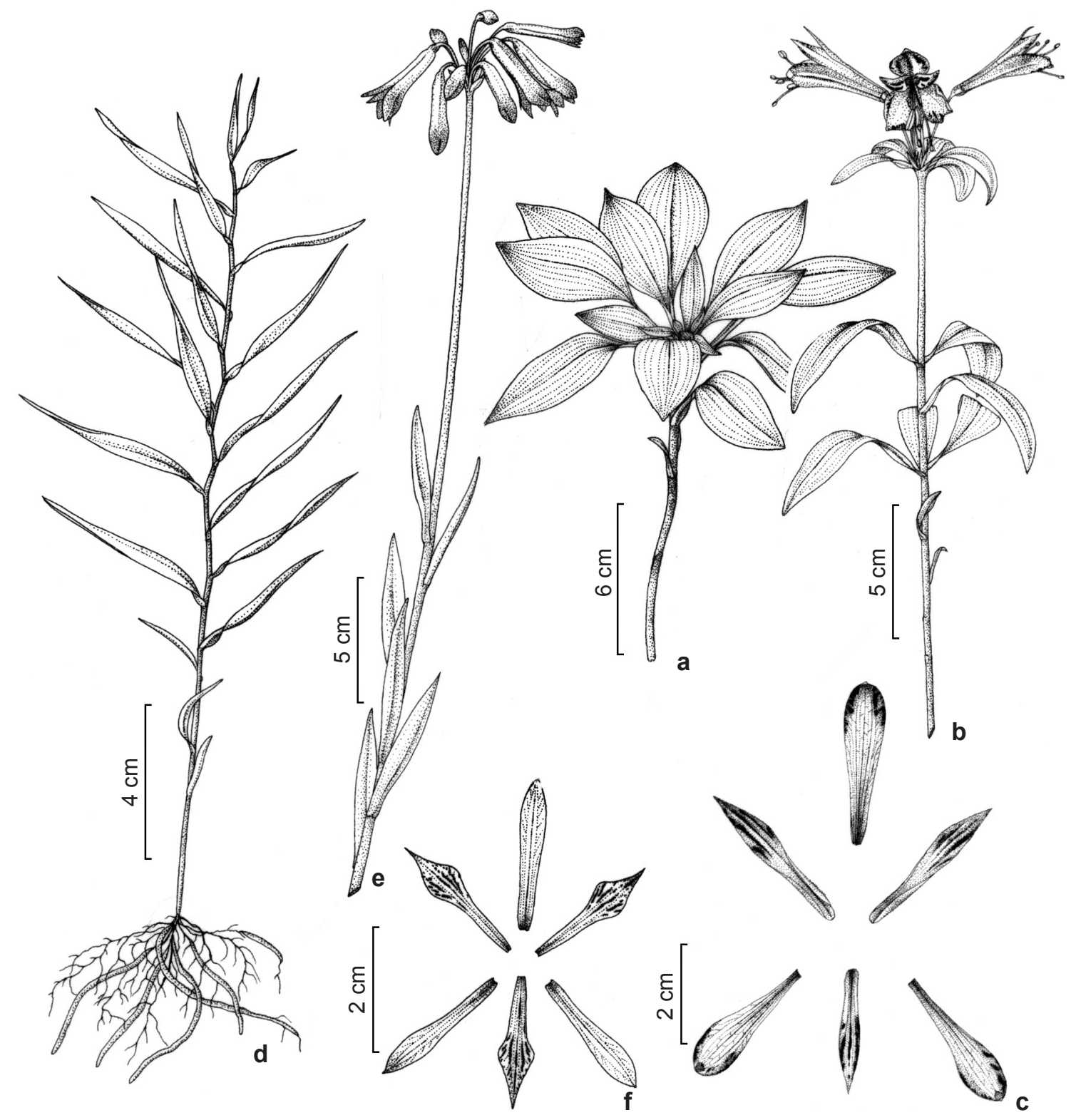

Figura 3 - a-c. A. inodora - a. parte do ramo vegetativo; b. parte do ramo reprodutivo mostrando brácteas desenvolvidas; c. flor mostrando tépalas externas rubro-variegadas e internas rubro-listradas (Assis 531). d-f. A. isabelleana - d. ramo vegetativo mostrando o rizoma e raízes de reserva delgadas; e. parte do ramo reprodutivo mostrando brácteas reduzidas, inflorescência umbeliforme simples e flores tubulosas e pêndulas; f. flor mostrando tépalas internas rubro-listradas e maculadas (Buzato, UEC 28014).

Figure 3 - a-c. A. inodora - a. part of vegetative branch; b. part of reproductive branch showing develop bracts; c. flower showing outer tepals red-variegated and inners red-striped (Assis 531). d-f. A. isabelleana-d. vegetative branch showing rhizome and slender reserve's roots; e. part of reproductive branch showing reduced bracts, umbel simple and pendulous and tubular flowers; f. flower showing inner tepals red-striped and stained (Buzato, UEC 28014). 
6. Alstroemeria isabelleana Herb., Amaryllidaceae 88, tab. 6 figs. 4-6. 1837. ("isabellana”) $A$. isabelleana Herb. var. longifolia Seub. ex Schenk. in Martius \& Eichler, Fl. bras.3: 171. 1855. A. campaniflora Hand.-Mazt., Denkschr. Kaiserl. Akad. Wiss., Wien. Math.-Naturwiss. K1. 79: 213. Tab. 19 figs. 2-6. 1908. A. regnelliana Kraenzl., Bot. Jahrb. Syst. 50 Beibl. 112: 3. 1913. A. butantanensis Hoehne, Revista Mus. Paul. Univ. São Paulo 11: 485. Tab. Única. 1919. A. viridiflora Ravenna, Onira 4(10): 34. 2000.

Fig. 3d-f

Erva ereta, 0,42-1,5 m alt.; ramos angulosos, papilosos a glabrescentes no terço proximal. Folhas do ramo vegetativo ressupinadas ou não, coriáceas, sésseis, distribuídas por todo o ramo, 3-16 × 0,5-1 cm; elíptico-lanceoladas, ápice acuminado ou arredondado, base atenuada, ambas as faces glabras com nervuras proeminentes, raro papilosa na face daxial., as do ramo reprodutivo ressupinadas ou não, semi-amplexicaules ou não amplexicaules, coriáceas, distribuídas no terço proximal do ramo, 3-16 × 0,5-1 cm; elíptico-lanceoladas, ápice acuminado ou arredondado, base atenuada, ambas as faces glabras com nervuras proeminentes, raro papilosa na face adaxial. Cimeira umbeliforme simples, pedicelo glabrescente, 1,5-4 cm compr.; brácteas ausentes ou membranáceas, 0,6-2 × 0,2$0,3 \mathrm{~cm}$; bractéolas membranáceas, $0,6-3 \times 0,2-0,3$ $\mathrm{cm}$. Flores pêndulas, sem odor, tubulosas, rosadas, alaranjadas, vermelhas, ou raro creme-esverdeadas, ápice esverdeado, 3-4,5 cm compr. Tépalas externas listradas ou sem máculas, similares entre si, oblongas a espatuladas, ápice acuminado a mucronado, base atenuada; a superior ca. 3,4 × 0,4 $\mathrm{cm}$; as inferiores ca. 3,4 $\times 0,5 \mathrm{~cm}$; tépalas internas rubro-listradas, iguais entre si, ca. $3,3 \times 0,5 \mathrm{~cm}$, espatuladas, ápice acuminado a cuspidado, base fortemente atenuada, margem distal inteira. Estames inclusos, filetes glabros, ca. 2,3 cm compr.; estigma incluso, estilete glabro, ca. 2,8 cm compr. Cápsula esferoidal, ca. 1,5-2 × 1,5-2 cm.

Material examinado: PARANÁ. Castro: Rio Iapó, elev. 1000 m, 31.X.1964, fl., G. Hatschbach 11763 (MBM); Curitiba: Rio Barigui, 2.III.1982, fl., G. Hatschbach 44620 (MBM). Palmas, Santo Agostinho, 13.XII.1966, fl., G. Hatschbach 15410 (MBM); $10 \mathrm{~km}$ nordeste de Palmas, 4.XII.1971, fl. e fr., G. Hatschbach 28174 (C, MBM). Piraí do Sul, J. Murtinho, 24.XI.1980, fl., G. Hatschbach 43366 (C, MBM, UEC). São Mateus do Sul, Rio Potinga, 9.XII.1971, fl e fr., G. Hatschbach 28447 (SP, UEC); 27.XI.1991, fl., G. Hatschbach \& C. Kockzicki 56110 (MBM, UEC, UPCB). Tibaji, Rodovia do Café, rio Capivari, 11.II.1976, fl., G. Hatschbach 38066 (MBM). RIO GRANDE DO SUL: Colônia São Pedro, estrada para
Torres, 31.X.1956, fl., H.W. Cordeiro 1 (UB). Bom Jesus, 15.I.1942, fl., B. Rambo (PACA 8811). Serra da Rocinha, 14.I.1942, fl., B. Rambo (PACA 8625); 19.I.1950, fl., $A$. Sehnem (PACA 50406).Cambará do Sul, 27.XII.1988, fl., J.A. Jarenkow \& R. M. Bueno 1158 (PEL). Canela, Caracol, 11.II.1947, fr., K. Emrich (PACA 35881); 12.II.1948, fl., K. Emrich (PACA 37220). Caxias, Vila Oliva, 16.I.1946, fl. e fr., B. Rambo (PACA 33179). Farroupilha, 25.XI.1957, fl., O. Camargo 2680 (PACA); Ijuí: Pestana, 7/II/1956, fl., J. Pivetta 1181 (PACA). Itaimbezinho, São Francisco de Paula, 30.I.1950, fl., B. Rambo (PACA 45601). Jari, Tupanciretan, 26.I.1942, fr., B. Rambo (PACA 10161). Montenegro, Campestre, 27.XII.1935, fl., C. Orth (PACA 33946); 27.XII.1935, fl., B. Rambo (PACA 2235). Kappesberg, 25.XII.1946, fl., F. Henz (PACA 35802). Pelotas, Horto Botânico, 18.XI.1955, fl., J.C. Sacco 419 (F, PACA, PEL). Rio Pardo, Passo de Olaria, 7.XI.1947, fr., J. Vidal 1601 (R). São Francisco de Paula, Fazenda Englert, 8.II.1941, fl., B. Rambo (PACA 4504). Cambará, II.1948, fl. e fr., B. Rambo (PACA 36621); 17.I.1963, fl. e fr., A. Sehnem 8155 (PACA). São Leopoldo, 1907. fl., F. Theissen 626 (PACA); I.1942, fl. e fr., J.E. Leite 322 (SP); 6.XI.1946, fl., C. Ritter (PACA 35323); 27.XII.1946, fl., H. Simas (PACA 35662); 17.XII.1948, fl., B. Rambo (PACA 38855). São Luiz, Cerro Largo, I.1943, fl., $P$. Buck (PACA 10883). São Mateus do Sul, Rio Potinga, 27.XI.1991, fl., G. Hatschbach \& C. Koczicki 56110 (MBM). São Salvador, 20.XII.1946, fr., F. Henz (PACA 66392). Vacaria, Fazenda da Ronda, 2.I.1947, fl. e fr., $B$. Rambo (PACA 34733). Passo do Socorro, 27.XII.1951, fl., B. Rambo (PACA 51649). SANTA CATARINA: Bom Retiro, Morro da Bela Vista, Campo dos Padres, 1957, fl., L.B. Smith \& R. Reitz 10477 (R); Estrada para Urubici, 2750'18'S 49³4'25', 6.XII.1995, fl., J.R. Stehmann et al. 1747 (BHCB, MBM); Campo dos Padres, 15.XII.1948, fl., R. Reitz 3729 (PACA); 23.I.1957, fl. e fr., B. Rambo (PACA 60219). São José, Serra da Boa Vista, 24.X.1957, fl., R. Reitz \& R. Klein 5358 (K). Urubici, Morro da Igreja, elev. 1700 m, 16.II.1995, fl. e fr., J.R. Stehmann \& A.O. Vieira 1294 (BHCB); 18.I.1994, fl., G. Hatschbach \& O.S. Ribas 61642 (BHCB, C, MBM, PEL); 16.II.1995, fl. e fr., G. Hatschbach et al. 61642 (MBM, SPF).

Alstroemeria isabelleana é encontrada na Argentina, Uruguai, Paraguai e Brasil, onde é freqüente em regiões brejosas, do Rio Grande do Sul a Minas Gerais. Floresce de outubro a fevereiro, às vezes até junho. Frutifica em janeiro, fevereiro, maio e setembro.

A. isabelleana caracteriza-se principalmente por apresentar flores tubulosas e pêndulas, tornando-a de fácil identificação. Suas flores apresentam uma grande variação de cores que vai do rosado ao vermelho-alaranjado ou creme-esverdeado.

O ramo vegetativo de Alstroemeria isabelleana é muito semelhante aos ramos vegetativos de A. albescens, A. apertiflora, A. malmeana e $A$. sellowiana que apresentam o ramo vegetativo 
coberto por folhas estreitas, cartáceas ou coriáceas, sendo muito difícil diferenciá-las no estágio vegetativo. Os principais caracteres distintivos entre estas espécies são os florais (Tab. 1).

7. Alstroemeria malmeana Kraenzl., Bot. Jahrb. Syst. 59 (112):3. 1913.

Fig. 4a-c

Erva ereta, 0,6-0,9 m alt.; ramos cilíndricos, papilosos no terço proximal. Folhas do ramo vegetativo não ressupinadas, coriáceas, semiamplexicaules, concentradamente distribuídas por todo o ramo, $3-9 \times 0,5-0,7 \mathrm{~cm}$, lineares ou linearlanceoladas, ápice acuminado, base cuneada, ambas as faces glabras, nervuras proeminentes na face adaxial, as do ramo reprodutivo não ressupinadas, amplexicaules, coriáceas, distribuídas na metade distal do ramo, 2,5-4,5 × 0,5-1 cm, lanceoladas ou estreitamente ovadas, ápice acuminado, ambas as faces glabras, nervuras proeminentes na face adaxial. Cimeira umbeliforme composta, pedicelos glabros, ca. 3,5-8 cm compr.; brácteas foliosas, cartáceas, $0,2-1 \mathrm{~cm}$ compr; bractéolas cartáceas, $0,3-0,7 \mathrm{~cm}$ compr. Flores pêndulas, sem odor, campanuladas a urceoladas, vermelhas, 1,8-2,2 cm compr. Tépalas não reflexas, externas sem máculas, similares entre si, espatuladas, ápice ligeiramente mucronado, base atenuada; a superior ca. $1,9 \times 0,6 \mathrm{~cm}$; as inferiores ca. $1,1 \times 0,6 \mathrm{~cm}$.; tépalas internas sem máculas, similares entre si, obovadas, ápice mucronado, base atenuada, margem distal inteira ou ligeiramente crenulada; as superiores ca. 1,9 $90,9 \mathrm{~cm}$; a inferior ca. $1,9 \times 1 \mathrm{~cm}$. Estames exclusos, filetes glabros, ca. 2,3 cm compr.; estigma excluso, estilete glabro, ca. 1,8 cm compr. Cápsula ovóide, ca. $1,4 \times 1,2 \mathrm{~cm}$.

Material examinado: PARANÁ: Palmas, 5.XII.1971, fl., G. Hatschbach et al. 28233 (MBM); Rodovia BR 280, ca. $15 \mathrm{~km}$ E de Palmas, 2.I.1999 fl. e fr., F. Meyer \& A.F.C. Tombolato (SPF, UEC 104381). SANTA CATARINA: Campos Novos, Rodovia BR-070, km 353, 12.II.1996, fl., C. B. Poliquesi et al. 489 (MBM).

Alstromeria malmeana é uma espécie rara, sendo encontrada nos campos úmidos do Rio Grande do Sul e Paraná, florescendo em janeiro e fevereiro e frutificando em janeiro.

Alstroemeria malmeana é facilmente reconhecível pelas folhas amplexicaules no ramo reprodutivo, as flores campanuladas a urceoladas e os estames e estigma exclusos. É próxima de $A$. sellowiana, diferenciando-se desta por apresentar inflorescências compostas, flores campanuladas a urceoladas e os estames e estigma exclusos, enquanto que $A$. sellowiana tem inflorescência simples, flores campanuladas e estames e estigma inclusos. Seus ramos vegetativos caracterizados por apresentar folhas estreitas, cartáceas ou coriáceas, dispersas por todo o ramo podem ser facilmente confundidos com os das espécies $A$. albescens, A. apertiflora, A. isabelleana e A. sellowiana. A distinção entre estas espécies é feita pelos caracteres florais (Tab. 1).

8. Alstroemeria psittacina Lehm., Ind. semin. hort. Hamburg. 17. 1826. Tipo: BRASIL. RIO GRANDE DO SUL. Maquiné: Estrada Maquiné-Barra do Ouro, 2.XI.1995, fl., J.R. Stehmann et al. 2175 (UEC!). Alstroemeria atrorubra Ravenna, Onira 4(10): 38. 2000. Tipo: BRASIL. MATO GROSSO. Bandeirante: Rodovia BR-163, 8.II.1974, fl., G. Hatschbach 33944 (MBM!), syn. nov. Fig. 4d-f

Erva ereta, 0,4-0,6 m alt.; ramos cilíndricos, glabros. Folhas do ramo vegetativo ressupinadas, não amplexicaules, membranáceas, concentradas no terço distal do ramo, 5-9(-13) $\times 1,4-3,2(-5,5)$ $\mathrm{cm}$, elípticas, oblanceoladas ou ovadas, ápice agudo, base atenuada, face adaxial papilosa, abaxial glabra, nervuras não proeminentes, as do ramo reprodutivo ressupinadas, não amplexicaules, membranáeas, distribuídas por todo o ramo, 1,7-4(-6,2) × 0,4$0,7(-1,8) \mathrm{cm}$, estreitamente elípticas ou elípticas, ápice agudo, base atenuada, face adaxial papilosa, abaxial glabra, nervuras não proeminentes. Cimeira umbeliforme simples, pedicelo glabro, $2,5-4 \mathrm{~cm}$ compr. Flores patentes, sem odor, campanuladas, vermelho-esverdeadas, ápice esverdeado, $4-4,5 \mathrm{~cm}$ compr., brácteas foliosas, membranáceas, 0,8-4 × $0,2-0,8(-1,5) \mathrm{cm}$. Tépalas externas rubro-maculadas, similares entre si, espatuladas, ápice apiculado, base atenuada; a superior 3,5-4,5 ×0,8-1 cm; as inferiores $3,3-4 \times 0,9-1 \mathrm{~cm}$.; tépalas internas rubro-maculadas, similares entre si, espatuladas, ápice cuspidado, base atenuada, margem distal inteira ou ligeiramente crenulada; as superiores 3,8-4 × 0,7 cm; a inferior $2-3 \times 0,5 \mathrm{~cm}$. Estames inclusos, filetes glabros, ca. $3 \mathrm{~cm}$ compr.; estigma incluso, estilete glabro, ca. 2,8 $\mathrm{cm}$ compr. Cápsula não vista.

Material examinado: PARANÁ: Curitiba, 6.XII.1961, fl., C. Stellfeld 1526 (UPCB). SANTA CATARINA: Petrolândia, Alto da serra, $27^{\circ} 35^{\prime} \mathrm{S} 49^{\circ} 44^{\prime} \mathrm{W}, 743 \mathrm{~m}$ alt. 3.XII.2002, fl., J.R. Stehmann et al. 3370 (BHCB).

Alstroemeria psittacina é encontrada na Argentina, Uruguai, Paraguai e no Brasil, nos estados de Mato Grosso, Mato Grosso do Sul, São Paulo, Paraná e Rio Grande do Sul, onde ocorre em locais sombreados no interior ou na orla de mata. Floresce em novembro, dezembro, fevereiro e maio e frutifica em novembro. 


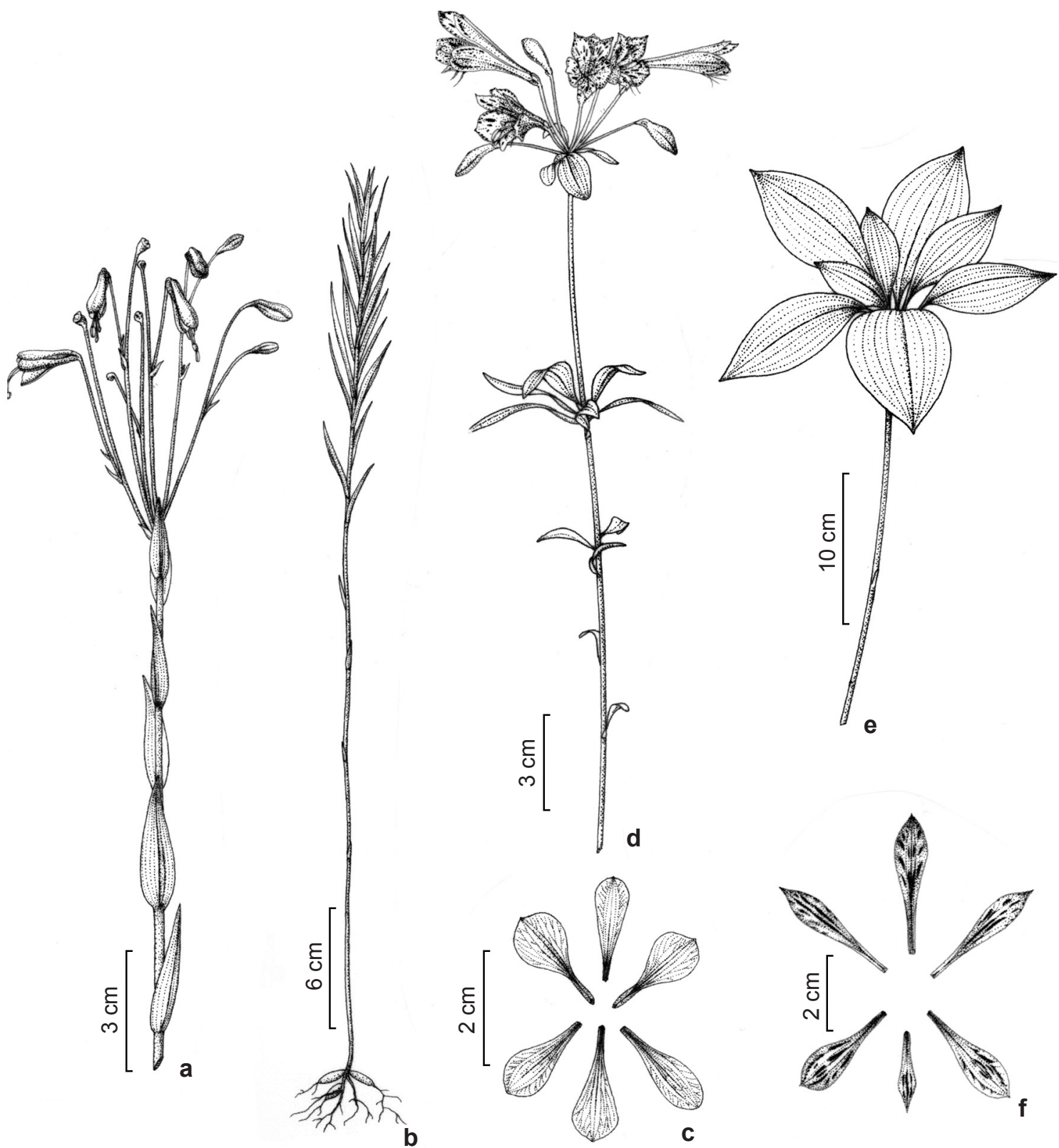

Figura 4 -a-c. A. malmeana - a. parte do ramo reprodutivo mostrando inflorescência composta; $b$. ramo vegetativo e c. flor mostrando tépalas sem máculas (Meyer s.n., UEC 104381). d-f. A. psittacina - d. ramo reprodutivo mostrando brácteas desenvolvidas; e. ramo vegetativo, f. flores mostrando todas as tépalas rubro-maculadas (Nave 1199).

Figure 4 - a-c. A. malmean - a. part of reproductive branch showing compound umbel; b. vegetative branch, c. flower showing untainted tepals (Meyer s.n., UEC 104381). d-f. A. psittacina - d. reproductive branch showing develop bracts; e. vegetative branch; f. Flowers showing outer and inner tepals red-stained (Nave 1199).

É caracterizada pelas flores vermelhas, com o terço distal verde, e por apresentar todas as tépalas rubro-maculadas. Esta espécie se assemelha muito a $A$. inodora e $A$. cunha das quais se diferencia pelas flores que em $A$. inodora apresentam as tépalas externas rubro-variegadas e internas rubro-listradas, e em $A$. cunha as tépalas externas não possuem máculas e as internas são rubro-maculadas e listradas.

Comparando-se o material Tipo de A. atrorubra com o material Tipo de $A$. psittacina, nota-se claramente que pertencem a mesma espécie. Por isso, aqui é designado a nova sinonímia. 
9. Alstroemeria sellowiana Seub. ex Schenk in Martius \& Eichler, Fl. bras. 3(15): 173. 1855.

Fig. 5a-c

Erva ereta, 0,3-0,51 m alt.; ramos angulosos, glabros. Folhas não ressupinadas, semiamplexicaules, coriáceas, as do ramo vegetativo concentradas no terço distal do ramo, 10,5-13,5 × 0,2-1,2 cm, linear-lanceoladas, ápice agudo, base cuneada, ambas as faces glabras com nervuras proeminentes, as do ramo reprodutivo distribuídas no terço distal do ramo, $0,8-4,5 \times 0,2-0,7 \mathrm{~cm}$, triangulares a elípticas ou lanceoladas, ápice agudo, base cuneada, ambas as faces glabras com nervuras proeminentes. Cimeira umbeliforme simples ou composta, pedicelo glabro, 1,1-2,5 cm compr.; brácteas foliosas, cartáceas ou coriáceas, $0,2-3,5 \times$ $0,1-0,4 \mathrm{~cm}$; bractéolas membranáceas, $0,2-1 \times 0,1-$ $0,2 \mathrm{~cm}$. Flores patentes, odoríferas, campanuladas, amareladas a alaranjadas, 2,1-3,2 cm compr. Tépalas externas sem máculas, similares entre si, espatuladas; a superior ca. 2,3 × 0,7 cm, ápice obtuso, base atenuada; as inferiores ca. 2,1 $\times 0,8$ $\mathrm{cm}$., ápice mucronado, ligeiramente unguiculado, base atenuada; tépalas internas rubro-punctadas, similares entre si, espatuladas; as superiores ca. 2,6 $\times 0,7 \mathrm{~cm}$, ápice mucronado, base atenuada, margem distal crenulada; a inferior ca. 2,2 $\times 0,7 \mathrm{~cm}$, ápice mucronado, base atenuada. Estames inclusos, filetes glabros, 1,5-1,8 cm compr.; estigma incluso, estilete glabro, 1-1,2 cm compr. Cápsula ovóide, $0,9-1,2 \times 0,8-1 \mathrm{~cm}$.

Material examinado: PARANÁ: Campo Largo, Serra do Purunã, 1.II.1983, fl. e fr., R. Kummrow 2223 (MBM). Guaratuba, Serra do Araçatuba, 21.I.1994, fl., R. Kummrow et al. 3369 (BHCB, MBM, UB). Horizonte, 24.XI.1981, fl., G. Hatschbach \& F. Hirzinker 44432 (MBM). Piraí do Sul, Joaquim Murtinho, 26.XI.1968, fl., G. Hatschbach 20385 (MBM). Piraquara, Serra do Emboque, 9.III.1971, fl., G. Hatschbach 26535 (MBM). RIO GRANDE DO SUL: Cambará do Sul, próximo a São Francisco de Paula, II.1948, fl., B. Rambo (PACA 36620); Serra da Rocinha, próximo a Bom Jesus, 12.II.1941, fl., B. Rambo (PACA 4622); 28.II.1946, fr., B. Rambo (PACA 32416); 14.II.1947, fr., B. Rambo (PACA 35302); 3.II.1953, fr., B. Rambo (PACA 53760). SANTA CATARINA: Bom Jardim, Estrada para Serra

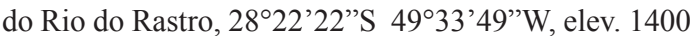
m, 18.I.1999, fl., F. Meyer \& A.F.C. Tombolato (UEC 104376). Campo Alegre, Rodeio Grande, subida para Serra do Iquererim, 10.I.1992, fl., O.S. Ribas \& E. Barbosa 433 (MBM). Lages, 10.I.1951, fl., B. Rambo (PACA 49559). Santa Cecília, ca. $90 \mathrm{~km}$ de Lages, elev. 900 m, 20.I.1952, fl. e fr., G.F.J. Pabst 10141
(RB). São Joaquim, Rio Capivaras, Serra do Oratório, 16.I.1957, fl., L.B. Smith \& R. Reitz 10122 (R). Urubici, Morro da Igreja, próximo ao alto, 17.II.1995, fl. e fr., $G$. Hatschbach et al. 61651 (BHCB, C, G, MBM, PEL); 18.I.1994, fl., J.R. Stehmann 1300 (BHCB).

Alstroemeria sellowiana é frequentemente encontrada em regiões brejosas, do Paraná ao Rio Grande do Sul. Floresce principalmente de novembro a fevereiro. Frutifica em janeiro e fevereiro.

Alstroemeria sellowiana, juntamente com A. caryophyllaea, espécie nativa de Minas Gerais e Rio de Janeiro, são as únicas espécies de Alstroemeria do Brasil com flores odoríferas.

A espécie mais próxima de $A$. sellowiana é $A$. amabilis, que apresenta tépalas internas e externas diferentes na forma, as internas rubro-listradas, enquanto que em $A$. sellowiana as tépalas internas e externas são semelhantes e as tépalas internas são rubro-punctadas. Além disso, não há registro de odor nas flores de A. amabilis. Outra espécie que pode ser confundida com $A$. sellowiana é A. malmeana, que tem flores campanuladas a urceoladas com os estames exclusos.

Em seu estado vegetativo Alstroemeria sellowiana pode ser confundida com $A$. albescens, A. amabilis, A. apertiflora, A. isabelleana e A. malmeana devido ao formato das folhas estreitas. No entanto, se diferenciam pelos caracteres florais (Tab. 1).

\section{Bomarea Mirb.}

Ervas eretas ou volúveis, raízes tuberosas ovóides. Ramos volúveis, cilíndricos, glabros, foliosos. Folhas ressupinadas, face abaxial papilosas raro glabras, lineares, lanceoladas ou oblongas. Inflorescência cimeira umbeliforme composta por inflorescências parciais, brácteas foliosas. Flores trímeras, perfeitas, epígenas, actinomorfas; perianto infundibiliforme a campanulado; tépalas externas sem máculas, obovada-oblongas; internas internamente rubromaculadas, espatuladas; estames 6 inseridos na base das tépalas; anteras basifixas, oblongas de deiscência introrsa e longitudinal; pistilo trilocular com estilete filiforme trífido. Fruto cápsula loculicida, depressa, turbinada, truncada no ápice, deiscência valvar; óvulos anátropos, placentação axilar ou parietal. Sementes numerosas, subglobosas, sarcotesta de cor roxolaranja brilhante. 


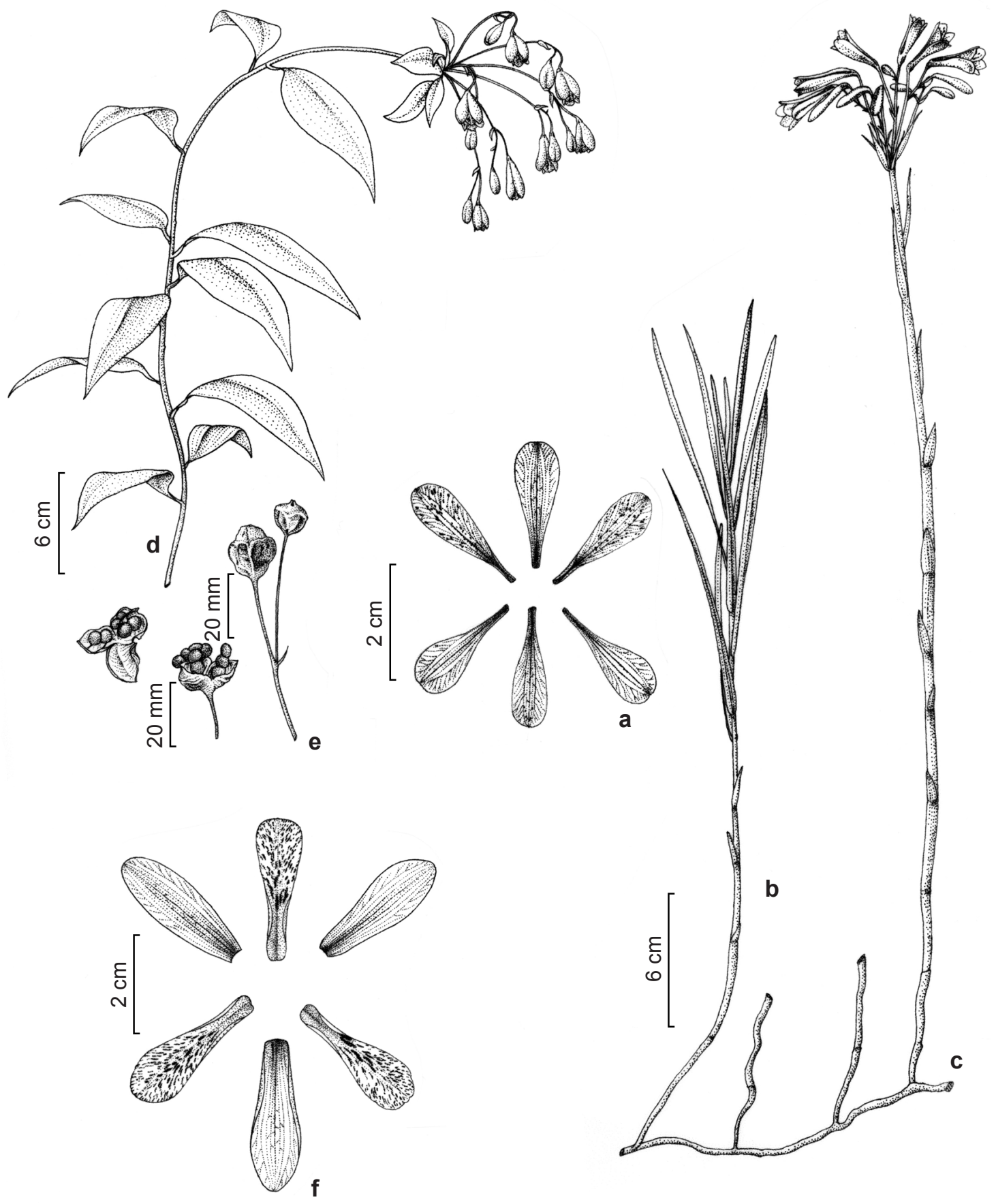

Figura 5 - a-c. A. sellowiana - a. flor mostrando tépalas internas e externas semelhantes entre si e tépalas internas rubro-punctadas; b-c. rizoma portando ramo vegetativo e reprodutivo respectivamente (Kummrow 2223). d-f. Bomarea edulis - d. hábito; e. frutos fechados e abertos; f. tépalas externas sem máculas e internas maculadas e variegadas (Assis 333).

Figure 5 - a-c. A. sellowiana - a. flower showing inner and outer tepals similar to each other and inners red-punctate; b-c. rhizome bearing vegetative and reproductive branch respectively (Kummrow 2223). d-f. Bomarea edulis - d. plant; e. open and closed fruit; f. outer tepals untainted and inner stained and variegated (Assis 333). 
Tabela 2 - Caracteres morfológicos distintivos entre as espécies Alstroemeria cunha, A. inodora e A. psittacina. Table 2 - Morphological characters distinguishing species Alstroemeria cunha, A. inodora and A. psittacina.

\begin{tabular}{llll}
\hline Caracteres & Alstroemeria cunha & Alstroemeria inodora & Alstroemeria psittacina \\
\hline Tépalas externas & Sem máculas & Rubro-variegadas & Rubro-maculadas \\
Tépalas internas & $\begin{array}{l}\text { Rubro-listradas e } \\
\text { maculadas }\end{array}$ & Rubro-listradas & Rubro-maculadas \\
Flores & Vermelho-alaranjadas & Vermelha & Vermelho-esverdeada \\
\hline
\end{tabular}

10. Bomarea edulis (Tussac) Herb. Amaryllidaceae: 111. 1837. B. brauniana Schenk in Martius \& Eichler, Fl. bras. 3(1): 168. 1855. B. hirta Schenk in Martius \& Eichler, Fl. bras. 3(1): 169. 1855. B. jacquesiana (Lem.) Kunth, Enum. pl. 5: 800. 1850. B. janeirensis M. Roem., Fam. nat. syn. monogr. 4: 267. 1847. $B$. maranensis Herb., Amaryllidaceae 422. 1837. B. martiana Schenk in Martius \& Eichler, Fl. bras. 3(1): 170. 1855. B. salsilloides (Mart.) M.Roem., Fam. Nat. Syn. 4: 264. 1847. B. spectabilis Schenk in Martius \& Eichler, Fl. bras. 3(1): 171. $1855 . \quad$ Fig. 5d-f

Ervas volúveis até $5 \mathrm{~m}$ alt., raízes de reserva ovóides. Folhas ressupinadas, oblongas ou oblongo-lanceoladas, 3,5-18 × 0,6-5cm, ápice acuminado a cuspidado, face abaxial papilosa, raro glabra. Inflorescência cimeira umbeliforme composta, pauci- ou multiradiada. Flores pêndulas, campanuladas, actinomorfas, rosadas, esverdeadas creme ou amareladas, $3-4,5 \mathrm{~cm}$. Brácteas foliosas, $1-4 \times 0,3-1,5 \mathrm{~cm}$. Tépalas externas sem máculas, oblanceoladas, oblongas ou obovadas, 2,6-4 $\times$ $1-1,5 \mathrm{~cm}$. Tépalas internas espatuladas, ápice retuso ou mucronado, 2,5-3,5 × 1-1,2 cm, internamente rubro-punctadas e variegadas. Sementes com sarcotesta vermelha-alaranjada.

Material examinado: PARANÁ: Bocaiuva do Sul: 29.XII.1975, fl., R. Kummrow 1007 (BR); 30.XII.1980, fl. R. Kummrow 1415 (UB). Campinhos, 29.XII.1946, fl., G. Hatschbach 588 (PACA). Cerro Azul, 5.I.1990, fl., J.M. Silva \& J. Cordeiro 777 (UPCB, W). Curitiba, 1.I.1953 fl., C. Stellfeld (UPCB 1364). Guaratuba, Ilha da Pescaria, 31.X.62, fl., E. Moreira 315 (UPCB).Piraquara, 1.I.1982, fl., Landrum 4039 (NY). Quedas do Iguaçú, Aldeia Pinhal, 23.I.1992, fr., N.R. Marquesini et al. (UPCB 21852). RIO GRANDE DO SUL: Bom Jesus, 16.I.1942, B. Rambo (PACA 9035); 26.XII.1982, fl., A. Krapovickas \& A. Schinini 38334 (CTES).Taimbezinho, 7.II.1941, B. Rambo (PACA 4313). Cambará, III.1948, fl., B. Rambo (PACA 36622). Campestre, 27.XII.1936, fl., B. Rambo (PACA 33947); 440 $\mathrm{m}$ alt. 15.XII.1949, fl., A. Sehnem (HUCS 2029). Canela, 23.II.1946, fr., K. Emrich (PACA 33266); 12.II.1948, fl., K. Emrich (PACA 37213); 31.I.1951, fl., K. Emrich (PACA 50182); 28.I.1953, fl., K.Emrich (PACA 52829). Caxias, II.1949, fl., B. Rambo (PACA 41104). Farroupilha,
28.XII.1956, fl., O. Camargo 1073 (PACA); 14.I.1957, fl., O. Camargo 1115 (PACA); 25.XI.1994, fl., G. Hatchbach \& O.S. Ribas 60369 (BHCB). Kappesberg, 27.XII.1946, fl., H. Simas (PACA 35774). Montenegro, 27.XII.1935, fl., B. Rambo 2258(W); 15.XII.1949, fl., A. Sehnem 4446(PACA). Morrinhos do Sul, Morro Azul, 30.XI.1996, fl., J.A. Jarenkow \& M. Sobral 3284 (PEL). Santa Rita, 29.I.1949, fl., B. Rambo (PACA 40324); 7.II.1950, fl. e fr., B. Rambo (PACA 45810, W). Vacaria, Faz. da Ronda, 3.I.1947, fl. e fr., B. Rambo (PACA 34732). SANTA CATARINA: Araranguá, Morro dos Conventos, 26.XI.1980, fl., A. Krapovickas \& R. Vanni 36972 (CTES). Imbituba, 3.XI.1973, fl., A. Sehnem 13869 (PACA). Lages, 16.I.1964, fl., E. Pereira \& G. Pabst 8407 (PEL). Laguna, Morro Nossa Senhora da Glória, 24.I.1984, fl., A. Krapovickas \& C.L. Cristóbal 39386 (CTES). Matos Costa, 3.XII.1995, fl., J.R. Stehmann \& A. Ippolito 1662 (BHCB). São Bento, I.1914, fl., A. Lutz 632 (R).

Espécie neotropical, amplamente distribuída pelo Brasil no interior e beira de matas. Floresce principalmente de novembro a janeiro.

Possui uma grande amplitude de variação tanto nas folhas, que podem ser largas, estreitas, pubescentes ou glabras, como nas flores, que podem ser róseas ou creme-esverdeadas, e na inflorescência que se apresenta pauci- ou multiradiada. Seu hábito volúvel e sua inflorescência umbeliforme, em geral bem vistosas, são caracteres marcantes que as distinguem do resto da família.

\section{Agradecimentos}

Agradeço à Empresa Brasileira de Pesquisa Agropecuária (EMBRAPA), pelo suporte financeiro e aos curadores dos herbários, que permitiram a análise dos materiais disponíveis nas coleções.

\section{Referências}

APG - Angiosperm Phylogeny Group III. 2009. An update of the Angiosperm Phylogeny Group classification for the orders and families of flowering plants: APG III. Botanical Journal of the Linnean Society 161: 105-121.

Assis, M.C. 2001. Alstroemeria L. (Alstroemeriaceae) do Brasil. Tese de Doutorado. Universidade de São Paulo, São Paulo. 165p. 
Assis, M.C. \& Mello-Silva, R. 2002. Flora da Serra do Cipó, Minas Gerais: Alstroemeriaceae. Boletim de Botânica Universidade de São Paulo 20: 49-52.

Assis, M.C. 2002. Novas espécies de Alstroemeria L. (Alstroemeriaceae) de Minas Gerais, Brasil. Revista Brasileira de Botânica 25: 177-182.

Assis, M.C. 2003. Duas novas espécies de Alstroemeria L. (Alstroemeriaceae) para o Brasil. Acta Botanica Brasilica 17: 179-182.

Assis, M.C. 2004a. New species of Alstroemeria L. (Alstroemeriaceae) from Brazilian savannas. Novon 14: $17-19$.

Assis, M.C. 2004b. Alstroemeriaceae no estado do Rio de Janeiro. Rodriguésia 55: 5-15.

Assis, M.C. 2006. A new species of Alstroemeria (Alstroemeriaceae) from Pará, Brazil. Brittonia 58: 267-269.

Assis, M.C. 2007. Flora dos estados de Goiás e Tocantins. Coleção Rizzo: Alstroemeriaceae. PRPPG/UFG, Goiânia. 49p.

Assis, M.C. 2009. A new species of Alstroemeria (Alstroemeriaceae) from Brazil. Novon 19: 145-149.

Boldrini, I. I. 2002. Campos Sulinos: caracterização e biodiversidade. In: Araújo, E.L.; Moura, A.N.; Sampaio, E.S.B.; Gestinari, L.M.S. \& Carneiro, J.M.T. (eds.). Biodiversidade, conservação e uso sustentável da flora do Brasil. UFRPE, Imprensa Universitária, Recife. Pp. 95-97.

Conrad, J.G. \& Cliford, H.T. 1998. Luzuriagaceae. In: Kubitzki, K. (ed.). The families and genera of vascular plants Vol. 3. Flowering plants. Monocotyledons: Liliane (except Orchidaceae). Springer-Verlag, Berlin. Pp. 365-368.

IUCN. 2003. Guidelines for application of IUCN red list criteria at regional levels. Version 3.0. IUCN Species Survival Comission, Gland and Cambridge. 26p.

Holmgren, P.K; Holmgren, N.H. \& Barnett, L.C. 1990. Index Herbariorum. Part I. The herbaria of the world. $8^{\text {th }}$ ed. Reg. Veg. New York Botanical Garden, New York. 120p.

MMA. 2007. Áreas prioritárias para conservação, uso sustentável e repartição de benefícios da biodiversidade brasileira: atualização. Portaria MMA n 9, de 23 de janeiro de 2007. Ministério do Meio Ambiente, Secretaria de Biodiversidade e Florestas, Brasília (Série Biodiversidade 31). 300p.

Sanso, A.M. \& Xifreda, C.C. 2001. Generic delimitation between Alstroemeria and Bomarea (Alstroemeriaceae). Annals of Botany 88: 10571069.

Sanso, A.M.; Assis, M.C. \& Xifreda, C.C. 2005. Alstroemeria a charming genus. Acta Horticulturae 686: 63-77.

Silva, D.W. 2002. Florestas com araucária-ocorrências e histórico. In: Araújo, E.L.; Moura, A.N.; Sampaio, E.S.B.; Gestinari, L.M.S. \& Carneiro, J.M.T. (eds.). Biodiversidade, conservação e uso sustentável da flora do Brasil. UFRPE, Imprensa Universitária, Recife. Pp. 98-100. 